\title{
UPAYA PENINGKATAN KOSAKATA BAHASA INGGRIS MELALUI STORYTELLING SLIDE AND SOUND
}

\author{
Dina Amelia ${ }^{1}$, Ely Nurmaily ${ }^{2}$ \\ Universitas Teknokrat Indonesia ${ }^{\mathbf{1}, 2,3}$ \\ amelia.dina@teknokrat.ac.id ${ }^{1}$, elynurmaily@teknokrat.ac.id ${ }^{2}$
}

\begin{tabular}{lll}
\hline Received: (29 Desember 2020) & Accepted: (1 Maret 2021) & Published : (30 Maret 2021) \\
\hline
\end{tabular}

\begin{abstract}
Education is held by modeling, building the will, and developing the creativity of students in the learning process. Children are individuals who are developing rapidly and are fundamental to the next life. Children at this age children aged 0-10 years are experiencing a rapid period in the development of human life (Uzer, 2019). Tunas Mekar Indonesia School is a national plus school that uses the language of instruction of English. However, since the Covid 19 pandemic and online learning began, the ability of students to be able to understand material and memorize vocabulary and speak English has decreased, especially children in grade 5 SD. This problem is also triggered by the learning methods that do not vary. The lecture and question and answer methods are the things most often used in classrooms. The method used by the PkM English Literature team at the Indonesian Technocrat University to improve English vocabulary is through Slide and Sound storytelling. Most of the PkM Storytelling Slide and Sound training participants gave fast and precise responses so that their vocabulary increased significantly during the training period. Meanwhile, a small proportion of students still have difficulty in composing words due to lack of vocabulary. However, all students felt a positive impact and all students were willing to cooperate and try out the learning method.
\end{abstract}

Keywords: English, Vocabulary, Slide and Sound, Storytelling, early childhood

\begin{abstract}
Abstrak
Pendidikan diselenggarakan dengan memberi keteladanan, membangun kemauan, dan mengembangakan kreativitas peserta didik dalam proses pembelajaran. Anak adalah sosok individu yang sedang berkembang dengan pesat dan fundamental bagi kehidupan selanjutnya. Anak pada usia masa ini anak berada pada usia 0-10 tahun sedang mengalami masa yang cepat dalam perkembangan hidup manusia (Uzer, 2019). Sekolah Tunas Mekar Indonesia adalah sekolah national plus yang menggunakan bahasa pengantar bahasa Inggris. Akan tetapi, sejak masa pandemic Covid 19 dan pembelajaran online dimulai, kemampuan siswa untuk dapat memahami materi dan menghafal kosakata serta berbicara dalam bahasa Inggris menurun, terutama anak-anak di kelas 5 SD. Permasalahan tersebut juga dipicu oleh metode pembelajaran yang tidak bervariasi. Metode ceramah dan tanya jawab merupakan hal yang paling seering digunakan di ruang kelas. Metode yang digunakan tim PkM Sastra Inggris Universitas Teknokrat Indonesia demi meningkatan kosakata bahasa Inggris adalah melalui storytelling Slide and Sound. Sebagian besar peserta pelatihan PkM Storytelling Slide and Sound memberikan respon cepat dan tepat sehingga mengalami peningkatan kosakata cukup signifikan selama masa pelatihan. Sementara Sebagian kecil siswa masih mengalami kesulitan dalam Menyusun kata dikarenakan kurangnya kosakata. Akan tetapi, semua siswa merassakan dampak positif dan semua siswa mau bekerjasama dan mencoba metode belajar tersebut.
\end{abstract}

Kata Kunci: Bahasa Inggris, Kosakata, Slide and Sound, Storytelling, usia dini 
To cite this article:

Amelia, Dina., \& Nurmaily, Ely. (2020). Upaya Peningkatan Kosakata Bahasa Inggris Melalui Storytelling Slide and Sound, Vol(1), 22-26.

\section{PENDAHULUAN}

Sebagai bahasa internasional Bahasa Inggris dibutuhkan untuk berkomunikasi secara global. Di era revolusi industri 4.0 dan masyarakat 5.0, bahasa Inggris menjadi bahasa komunikasi yang paling umum dan paling penting. Oleh karena itu, bahasa Inggris dipelajari oleh semua kalangan di Indonesia. Namun, pada kenyataannya, di Indonesia, bahasa Inggris termasuk bahasa yang dianggap sulit untuk dikuasai atau dipelajari bahkan oleh anak-anak usia dini yang notabennya masih berada pada taraf "golden age". Tantangan terbesar yang ditemukan di lapangan adalah bukan hanya anak-anak tidak suka belajar bahasa Inggris melainkan juga metode pembelajaran yang tidak up to date dan cenderung membosankan Cameron (2001). Berdasarkan Undang-Undang Dasar Nomor 20 Tahun 2003 tentang sistem Pendidikan Nasional pasal 4 ayat 4 tentang prinsip penyelenggaraan Pendidikan bahwa Pendidikan diselenggarakan dengan memberi keteladanan, membangun kemauan, dan mengembangakan kreativitas peserta didik dalam proses pembelajaran. Menurut hasil penelitian Osbora, White, dan Bloom dalam Michelle (2017) perkembangan intelektual manusia pada usia empat tahun sudah mencapai $50 \%$, usia 8 tahun $80 \%$, dan pada usia 18 tahun bisa mencapai $100 \%$. Penelitian tersebut menjelaskan bahwa golden age adalah masa dimana seorang anak menyerap segala sesuatu yang ada di sekitarnya, serta mempengaruhi perkembangan anak secara mental dan kepribadian (Fitriana dan Kusrihandayani, 2017).

Pada pelaksanaannya pembelajaran bahasa Inggris memerlukan metode belajar yang menyenangkan bagi siswa dan juga dapat membanngun rasa percaya diri motivasi, dan kreativitas siswa. (Uzer, 2019). Salah satu cara yang dapat digunakan dalam pembelajaran bahasa Inggris adalah dengan menggunakan metode storytelling tepatnya metode slide and sound. Metode tersebut seringkali digunakan dalam kompetisi bahasa Inggris. Menurut penelitian yang ditulis oleh Setyarini (2012) mengimplementasi Storytelling dalam pembelajaran dapat meningkatkan kemampuan berbicara, tata bahasa, pengucapan, dan kosakata. Metode ini juga dapat memberikan efek yang luar biasa dalam hal perkembangan bahasa lisan dan kesadaran tentang bagaimana orang lain melihat dunia karena dapat membantu pemahaman multikultural siswa (Yamin 2017). Wright (2003) mengatakan bahwa pemahaman anak-anak tentang cerita meningkat ketika mereka turut serta dalam bercerita sehingga mengasah kemampuan bahasa mereka. Salah satu sekolah yang menggunakan bahasa Inggris sebagai bahasa pengantar dalam pembelajaran sehari-hari adalah sekolah dasar Tunas Mekar Indonesia. Sekolah tersebut merupakan sekolah national plus yang melaksanakan pembelajaran kurikulum lokal dan menyampaikannya dalam bahasa Inggris. Bagi Sebagian siswa di sekolah dasar tersebut storytelling bukanlah hal yang asing dikarenakan sekolah tersebut kerap kali mengirimkan siswanya untuk ikut serta dalam berbagai cabang lomba bahasa Inggris. Akan tetapi, berdasarkan observasi, ternyata siswa belum mengenal metode slide and sound. Oleh karena itu, tim PkM Sastra Inggris UTI berinisiatif untuk memperkenalkan metode tersebut sehingga dapat membantu anak-anak untuk menambah kosakata dan meningkatkan kemampuan berbicara mereka.

\section{TELAAH PUSTAKA}

\section{Penggunaan Storytelling dalam Pembelajaran Sastra Inggris}

Metode yang digunakan dalam PkM Sastra Inggris UTI terhadap siswa SD Sekolah Tunas Mekar Indonesia adalah metode storytelling slide and sound (digital storytelling). Boltman dalam Marfuaty \& Wahyudi (2016) mengatakan bahwa storytelling adalah kemampuan seseorang untuk membuat dan menampilkan suatu narasi baik dalam bentuk syair maupun cerita. Storytelling hampir sama dengan drama, metode ini dilaksanakan datunjukkan melalui penampilan dalam sebuah pertunjukkan di depan khalayak ramai (penotnton). Cara penyampaianannya dapat menggunakan music atau tidak sama sekali. Penggunaan alat-alata peraga atau property juga sangat mendukung dalam menamplkan storytelling.

Storytelling atau mendongeng sesungguhnya bukanlah hal baru dalam bidang pembelajaran serta komba bahasa Inggris. Kenyataannya mendoengeng adalah sebuah tradisi budaya lisan yang telah dilakukan slama berabad-abad lamanya (Setyarini, 2015). Menurut Ellis \& Cameron (2001) storytelling kaya akan kosakata dikarenakan cerita yang ditampilkan memiliki konteks dan berbagai alat peraga termasuk gambar dan tariantarian. Oleh karena itu storytelling menjadi metode yang tepat bagi anak-anak untuk belajar mengkhafal serta memahami suatu bahasa. Dalam PkM Sastra Inggris UTI ini, metode storytelling yang digunakan adalah dengan menggunakan slide and sound atau slide (lembar PowerPoint) dan Bunyi. 
Storytelling merupakan metode yang telah sering digunakan dalam pembelajaran bahasa Inggris. Cahyati et al (2019) sebelumnya telah menggunakan metode digital storytelling yang ternyata sangat dimiinati oleh guru dan siswa SMP di wilayah Subang. Dalam penggunaan metode tersebut para siswa dan guru dapat belajar bersama dan fokus kepada pembahasan membaca, mendengar, melihat, mengucapkan, dan melakukan. Semua kemampuan tersebut dapat diperoleh melalui pembelajaran dengan metode storytelling.

Selanjutnya, Setyarini (2015) yang menggunakan metode storytelling pada pembelajaran bahasa Inggris untuk anak usia dini kelas 4 SD PN Setiabudhi. Metode iini digunakan untuk mengenal jenis cerita apa saja yang disukai oleh anak-anak usia dini sehingga dapat meraih perhatian mereka. Selain itu guru juga belajar untuk mengimplementasikan cara yang tepat untuk meningkatkann kemampuan bahasa Inggris siswa didik mereka.

Tidak hanya itu, Rizky \& Suharmoko (2019) juga telah menggunakan metode yang sama untuk meningkatkan kemampuan berbicara siswa SMK N 3 kota Sorong. Melalui metode tersebut mereka menunjukkan bahwa setelah menggunakan metode storytelling dalam belajar bahasa Inggris kemampuan berbicara peserta didik menjadi meningkat dengan signifikan. Mereka menjadi lebih imajinatif dan paham akan konteks pembahasan dalam sebuah percakapan.

\section{METODE PELAKSANAAN}

PkM Sastra Inggris UTI dilaksanakan pada tanggal 13 dan 14 November 2020 di SD Tunas Mekar Indonesia. Kegiatan PkM dilaksanakan selama 2 jam dan didapmingi oleh guru wali kelas serta guru pendamping. Sasaran dari pelathan dengan metode storytelling slide and sound ini adalah siswa/I kelas 5 SD di sekolah yang telah dituju. Data dikumpulkan melalui observasi dan interview yang dilakukan terhadap guru dan siswa.

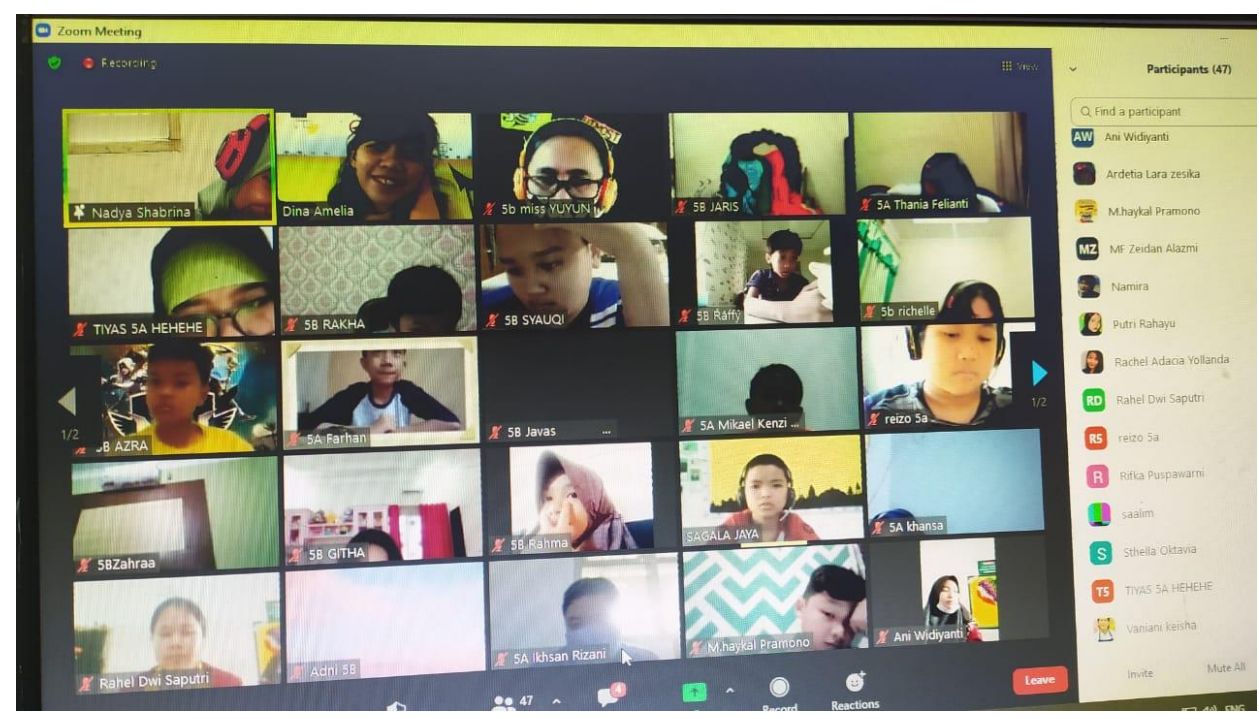

Gambar 1. Pelatihan storytelling slide and sound

\section{Metode Pengabdian}

1. Identifikasi masalah; tim pelaksana mengunjungi SD Tunas Mekar Indonesia dan kemudian melakukan survei observasi untuk mengetahui apa saja permasalahan yang dihadapi oleh siswa SD kelas 5 Tunas Mekar Indonesia,

2. Perencanaan kegiatan berdasarkan permasalahan; setelah mengetahui permasalahan yang dihadapi oleh para siswa, tim pelaksana kemudian menysun rencana pelatihan dan metode yang tepat guna,

3. Pelaksanaan kegiatan; tim pelaksana kemudian menjalankan pelatihan yang telah direncanakan oleh tim PkM. Siswa yang ikut serta dalam pelatihan tersebut berjumlah 34 orang siswa dan 3 orang guru yang terdiri 
dari 2 orang homeroom teachers dan satu orang sliding teacher. Sedangkan mahasiswa yang ikut serta dalam PkM berjumlah 8 orang dan dosen berjumlah 2 orang.

4. Pada saat pelaksanaan tim PkM Sastra Inggris UTI menampilkan gambar dan memperdengarkan suara. Gambar dan suara yang digunakan merupakan gambar dan suara yang sangat dikenal oleh para siswa. Seperti misalnya gambar rumah dan bola, suara mobil atau binatang. Siswa kemudian diajak untuk Menyusun cerita dengan menggunakan gambar dan suara tersebut.

5. Observasi; selama masa pelatihan, tim pelaksana melakukan observasi terhadap peserta pelatihan.

Evaluasi (observasi dan tes latihan); tim pelaksana mengadakan tes untuk melihat perkembangan pada peserta pelatihan dan mengevaluasi hasil pelatihan, Perencanaan selajutnya; jika diperlukan pelatihan selanjutnya, maka tim pelaksana akan menyusun Kembali program berikutnya.

\section{HASIL DAN PEMBAHASAN}

Pengabdian ini dilakukan dalam 2 hari.

1. Hari pertama, 13 November 2020, merupakan tahap pengenalan dan uji coba. Pada hari pertama tim PkM menemukan bahwa para siswa beserta guru tidak memiliki pengalaman dalam bidang storytelling slide and sound sehingga timi PkM lebih banyak menghabiskan waktu dengan mengenalkan metode tersebut. Pada hari pertama siswa terkesan malu-malu dikarenakan siswa masih beradaptasi dengan anggota tim PkM. Akan tetapi, di sesi ke-2 atau 1 jam ke-2 para siswa mulai memahami konsep dan semakin lama semakin tertarik terhadap metode pembelajaran tersebut sehingga semakin banyak peserta yang berani mencoba. Tim PkM Sastra Inggris UTI juga menggunakan gambar serta suara yang dikenal oleh anak-anak sehingga mereka tidak harus berpikir keras.

2. Hari kedua, 14 November 2020, Sebagian besar siswa tidak lagi malu-malu ikkut serta dalam storytelling slide and sound. Tim PkM Sastra Inggris UTI menunjukkan gambar dan suara yang mudah dipahami dan membuat siswa tertawa serta berinteraksi dengan leluasa. Sebagian besar siswa dapat langsung menyambung cerita dari gambar sat uke gambar lainnya atau dari suara sat uke suara lainnya yang menjadikan kegiatan lebih menyenangkan.

3. Setelah menyelesaikan kegiatan, tim PkM melakukan sesi tanya jawab terhadap para siswa. Banyak diantara mereka yang merasa tidak kesulitan dalam mengikuti pelatihan sehingga mereka tidak bertanya, sementara siswa yang lainnya masih malu-malu untuk bertanya.

4. Terakhir, tim PkM menyempatkan diri untuk bertanya kepada siswa dan guru mengenai kegiatan tersebut. Siswa dan guru merasa bahwa kegiatan tersebbut merupakan kegiatan yang menyenangkan dan memberikan dampak positif karena mampu memotivasi dan mendorong kreativitas siswa. Oleh karena itu, pihak sekolah kembali menawarkan untuk mengadakan kerjasama setelah pandemic Covid 19 berakhir.

5. Pertanyaan yang ditanyakan oleh tim PkM Sastra Inggris UTI adalah:

1. Bagaimana pendapat anda terhadap kegiatan PkM hari ini?

2. Apa saja manfaat kegiatan ini menurut anda?

3. Apa yang dirasakan selama mengikuti kegiatan PkM?

4. Apakah anda ingin mengadakan kegiatan yang sama di masa mendatang?

5. Kesulitan apa yang anda temui selama belajar storytelling slide and sound?

\section{KESIMPULAN}

Berdasarkan data yang diperoleh oleh tim PkM Sastra Inggris UTI hasilnya menunjukkan bahwa:

1. Para Guru mendapatkan referensi belajar bahasa Inggris untuk menambah kosakata bagi para siswanya.

2. Para siswa dapat lebih berani dalam mencooba untuk berbicara dalam bahasa Inggris karena mandapatkan lebih banyak kosakata. 
3. Para guru dan siswa menjadi termotivasi dan lebih kreatif dalam belajar bahasa Inggris.

\section{UCAPAN TERIMA KASIH}

Tim PkM Sastra Inggris UTI mengucapkan terimakasih kepada Universitas Teknokrat Indonesia yang telah membiayai kegiatan PkM sehingga dapat berlangsung dengan tepat guna.

\section{DAFTAR PUSTAKA}

Undang-Undang Dasar Nomor 20 Tahun 2003 Nomor 20 Tahun 2003 sistem Pendidikan Nasional berkaitan dengan Pendidikan Anak Usia Dini

Cahyati et al. (2019). Pelatihan Pemanfaatan Media Digital Storytelling dalam Pembelajaran Bahasa Inggris Bagi Guru SMP Wilayah Subang. Jurnal Pengabdian Kepada Masyarakat, 2(2), 147 - 154.

Cameron, L. 2001. Teaching Languages to Young Learners. Cambridge University Press.

Fitriana, Rahmawati, \& Kusrihandayani, Dyah. 2017. “Analisis Kebutuhan Penerapan Pembelajaran Bahasa Inggris Berbasis Cerita Rakyat Kutai Kartanegara di Sekolah Dasar di Kabupaten Kutai Kartanegara. SNITT-Politeknik Negeri Balikpapan.

Michelle, Bram Irene., \& Rizkia, Mikael Ray. (2017). Laporan Praktik Lapangan CB Pancasila di PAUD Mawar Indah. Diakses dari : https://www.google.co.id/amp/s/bim2r2.wordpress.com/2017/05/14/laporankegiatan-pengajaran-paud/amp/ pada 14 Juni 2020 pukul 15.00

Marfuaty, F. A., \& Wahyudi, R. (2015). An analysis of thematic progression patterns: Opinion section texts of The Jakarta Post, 9(3), 109-130.

Setyarini, Sri. (2012). Pengembangan Model Pembelajaran Berbasis Storytelling: Sebuah Terobosan dalam Upaya Meningkatkan Output Pembelajaran Bahasa Inggris Anak Usia Dini.

Uzer, Yus Vernandez. (2019). "Strategi Belajar Bahasa Inggris yang Menyenangkan untuk Pendidikan Anak Usia Dini. Pernik Jurnal PAUD, vol. 2, no. 1, pp. 1-9.

Wright, A. 2003. "The Place of stories in ELT” in A. Paran \& E. Watts (eds.) Storytelling in ELT. Kent: IATEFL Publications, 7-10.

Yamin, M. 2017. “Metode Pembelajaran Bahasa Inggris di Tingkat Dasar”. Jurnal personal Dasar, vol. 1, no. 5, pp. 82-97. 